\title{
Penerapan Metode Data Mining Pada Point of Sale Berbasis Web Menggunakan Algoritma Apriori
}

\author{
Adam Firmansyah, M Iwan Wahyudin, Ben Rahman* \\ Fakultas Teknik Komunikasi Informatika, Informatika, Universitas Nasional, Jakarta, Indonesia \\ Email: ${ }^{1}$ Adamfirmansyah2603@gmail.com, ${ }^{2}$ iwan_wyd@yahoo.com, ${ }^{3, *}$ ben.rahman@gmail.com \\ Email Penulis Korespondensi: ben.rahman@gmail.com
}

\begin{abstract}
Abstrak-Untuk dapat memahami produk mana yang telah dibeli pelanggan, dilakukannya dengan menggambarkan kebiasaan saat pelanggan membeli. Menggunakan aturan asosiasi untuk mendeteksi barang yang dibeli di waktu yang sama . Pengkajian ini menggunakan algoritma apriori akan menentukan aturan asosiasi saat membeli barang. Hasil pengkajian dan menganalisi data mendapatkan pernyataan bahwa menggunakan algoritma apriori untuk memilih gabugngan itemset memakai support minimal $25 \%$ dan confidence minimal $100 \%$, ditemukan aturan asosiasi yaitu, jika pelanggan membeli diwaktu yang sama.Membeli barang memiliki nilai dukungan dan kepercayaan tertinggi. Begitu pula dengan nilai support sebesar 25\% maka nilai confidence sebesar $100 \%$. Dengan cara ini, jika ada pelanggan yang membeli barang, bahwa probabilitas pelanggan membeli barang tersebut yaitu $100 \%$.
\end{abstract}

Kata Kunci: Data Mining; Algoritma Apriori; Aturan Asosiasi; Support; Confidience

\begin{abstract}
To be able to understand which products have been purchased by customers, it is done by describing the habits when customers buy. Use association rules to detect items purchased at the same time. This study uses an a priori algorithm to determine the association rules when buying goods. The results of the study and analyzing the data obtained a statement that using the a priori algorithm to select the combined itemset using a minimum support of $25 \%$ and a minimum confidence of $100 \%$, found the association rule, namely, if the customer buys at the same time. Buying goods has the highest value of support and trust. Likewise with the support value of $25 \%$, the confidence value is $100 \%$. In this way, if a customer buys an item, the probability that the customer buys the item is $100 \%$.
\end{abstract}

Keywords: Data Mining; Algortms Apriori; Association Rules; Support; Confidience

\section{PENDAHULUAN}

Memasarkan penjualan menjadikan fungsi yang sangat penting dan menentukan bagi para pebisnis. Pada penelitian ini, dilakukan penelitian pada toko andra jaya. Untuk mendapatkan tujuan keuntungan demi kelangsungan hidup toko andra jaya. Toko andra jaya adalah toko yang menjajakan segala bentuk busana pria dan wanita. Toko andra jaya menjual pakaian lokal kualitas export Toko Andra Jaya berlokasi di Pasar Jaya Cibubur bks 099, Jalan Lapangan Tembak, Desa Cibubur, Kecamatan Ciracas. Sistem penjualan toko busana andra jaya, konsumen langsung mendatangi toko untuk memilih baju yang mau dibelanjakan. Kegiatan promosi yang dilayani oleh toko busana andra jaya masih kurang, banyak pelanggan yang tidak menyadari bahwa toko busana andra jaya menjajakan busana yang berkualitas tinggi. Dalam pengkajian ini, digunakan algoritma apriori dan aturan asosiasi, penulis bisa menggambarkan hasil belanja pelanggan. Aturan asosiasi merupakan sistem menggali data yang berfungsi bagi, mendapatkan aturan asosiasi pada jarak gabungan proyek tertent. Diwaktu yang bersamaan, awalnya alogritma digagaskan oleh Agrarawal dan Srkant di tahun 1994 untuk mendapatkan item dari aturan asosiasi Bolean.

Data mining adalah ilmu menambang data dalam database yang besar untuk mendapatkan informasi yang berharga dan berguna. Dalam teknologi data mining yang terpenting yaitu aturan untuk menentukan sistem frekuensi tinggi dalam set item, disebut dengan aturan asosiasi. Pencarian pola asosiasi berawal dari pengolahan data transaksi penjualan buku, kemudian dicari hubungan antar buku yang dibeli. Proses pencarian asosiasi ini menggunakan bantuan algoritma apriori yang merupakan algoritma yang digunakan untuk menghasilkan association rule dengan pola "if then" yang berfungsi untuk membentuk kombinasi item yang mungkin, kemudian diuji apakah kombinasi tersebut memenuhi parameter support dan confidence minimum yang merupakan nilai ambang yang diberikan oleh user[1].

Banyaknya persaingan di dunia bisnis, khususnya dalam industri penjualan pupuk, menuntut manajemen untuk menemukan suatu strategi yang dapat meningkatkan penjualan. Agar dapat mengetahui pupuk apa saja yang dibeli oleh para konsumen, dapat dilakukan dengan teknik analisis yaitu analisis dari kebiasaan membeli konsumen. Pendeteksian mengenai pupuk yang sering dibeli secara bersamaan dilakukan dengan menggunakan association rule (aturan asosiasi), yang mana proses pencarian asosiasi atau hubungan antar item data ini diambil dari data transaksi penjualan pupuk harian di CV [2]. Pemahaman dan definisi yang tepat akan suatu masalah merupakan hal yang penting dalam menciptakan suatu solusi software yang tepat[3].Data tersebut hanya digunakan sebagai acuan untuk membuat laporan penjualan serta menjadi arsip saja [4].

\section{METODOLOGI PENELITIAN}


Algoritma apriori merupakan salah satu algoritma yang menggunakan penelurusan frequent itemset berdasarkan teknik aturan asosiasi[5]. Algoritma ini mengatur calon itemset dari hasil frequent itemset dengan support based pruning untuk menghilangkan itemset yang menolak dengan menetapkan minus. Algoritma apriori memakai sebuah pemahaman freakuensi karakter yang telah dikenal untuk mengerjakan suatu informasi lanjutan[6]. Sedangkan algoritma apriori menunjuk calon yang hadir yaitu menggunakan sistem terhadap minimum confidence dan minimum support. Support ialah jumlah persentase atau pengunjung campuran sebuah pilihan pada database[7]. Salah satu bagian analisis asosiasi yang menyeret banyak minat dari pengkaji untuk mendapatkan algoritma yang efektif yaitu analisis sistem frekuensi tinggi (frequent pattern mining). Satu asosiasi mampu dikenal penting setidaknya memakai dua tolak ukur ialah : confidence dan support. Support( nilai penunjang) ialah persentase gabungan item yang tercatat dalam database, sedangkan confidence (nilai kepastian) yakni kompeten pada koneksi antar item dalam aturan asosiasi. Tiap literasi pada algorima apriori terdapat pola saluran yang tinggi sehingga literasi pertama menghasilkan sebuah pola dengan frekuensi yang tinggi dengan Panjang satu[8]. Berikut ini adalah tahapan pada algoritma apriori :

1. Menelusuri pada kandidat item set (K-itemset).

2. Pemilihan pada sistem frekuensi tinggi yang tercantum bagi standard item pada sistem frekuensi yang tinggi yaitu item support melampaui ketentuan dari minimum support.

Misalnya tidak dapat sistem frekuensi yang tinggi, proses nya akan di hentikan dan balik ke tingkatan pertama. Berikut adalah contoh cara kerja algoritma apriori menggunakan flowchart:

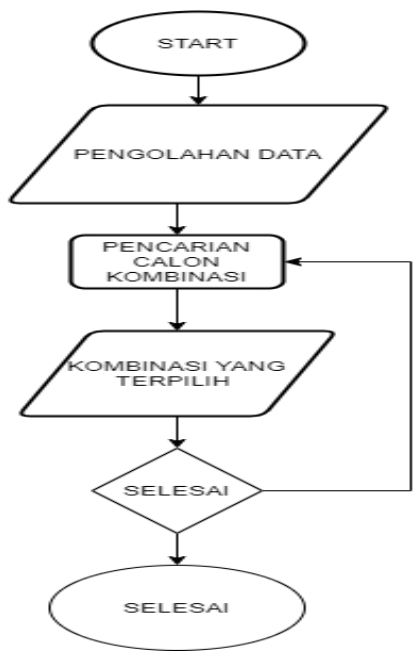

Gambar 1. Flowchart Algoritma Apriori

\subsection{Aturan Asosiasi}

Asosiasi Rules yaitu teknik untuk memperlihatkan sebuah gabungan atau koneksi diantara item. Asosiasi rules merupakan suatu metode data mining yang digunakan aturan asosiasi untuk mendapatkan antara suatu gabungan. Rancangan implementasi sistem yang menperilihatkan limit dan keahlian dari kegunaan utama dari struktur yang di anjurkan [9]. Ketika rancangan terbentuk, disampaikan lah kepada pemakai untuk dipertimbangkan. Rancangan dapat membantu pemakai menunjukkan cara sebuah fitur dapat berguna di perangkat lunak akhir. Saran dapat diberikan oleh pemakai dalam perbaikan pada rancangan. Kelompok tim pengembang dapat mengaplikasikkan saran pada rancangan terbaru, telah dilakukan evaluasi oleh pemakai. Aturan assoiasi dapat membentuk beberapa besar gabungan antaara $\mathrm{X}$ dan $\mathrm{Y}$ dan dibutuhkan dua tingkatan pada aturan ini, yaitu confidence dan support[10]. Metode yang dipakai ada dua tahap yaitu:

1. Penjabaran di sistem frekuansie nilai tinggi. di bagian ini, persyaratan minimum dapat melengkapi gabungan item pada dukungan nilai di database. Nilai kontribusi didapatkan (support) p menggunakan rumus berikut:

$$
\text { Support }(A)=\frac{\text { Jumlah Transaksi Mengandung A }}{\text { Total Transaksi }}
$$

2. Didapatkan nilai dukungan rumus dari 2 item berikut, yaitu:

$$
\text { Support }(A \cap B)=\frac{\text { JumlahTransaksi Mengandung } A \text { dan } B}{\text { Total Transaksi }}
$$

Untuk mendapatkan sistem frekuensi tertinggi metode asosiasi ditetapkan, Persyaratan untuk mendapatkan metode asosiasi, metode asosiasi dihitung dengan nilai ketentuan minimum[11]. "A maka B" $=(\mathrm{A} \rightarrow \mathrm{B})$ dan rumusnya seperti berikut: 


$$
\text { Confidience }=P(A \mid B)=\frac{\text { Jumlah Transaksi Mengandung } A \text { dan } B}{\text { Jumlah Transaksi Mengandung } A}
$$

\subsection{Data Mining}

Laporan suatu data yang penting merupakan proses dari data mining. Data ini mendapatkan prosedur yang susah seperti memakai artificial intelligence, teknik statistik, ilmu matematika, machine learning, dan lain lain. Mengenali sistem yang rumit ini maka tambahan informasi yang berguna pada satu penyimpanan besar[12]. Data mining ini mempunyai banyak fungsinya. Melainkan, dari tujuan utama fungi tersebut ialah descriptive dan fungsi predictive. Kegunaan data mining yang, yaitu: characterization, discrimination, association, classification, clustering, outlier and trend analysis, dan sebagainya. Menurut aggarawal data mining ialah sebuah studi analisis, pemrosesan, pengumpulan, pembersihan dan memperoleh manfaat wawasan dari sebuah data[13]. Ada banyak variasi dalam hal domain masalah, representasi, data aplikasi dab formulasi yang ditemui dalam aplikasi nyata Serangkaian metode data mining menggambarkan metode yang mencari nilai tambah yang selama ini tidak diketahuii dengan manual, pada basis data yang mengerjakan penggalian sistem - sistem pada data untuk melakukan manipulasi data sebagai laporan yang beharga dan didapatkan menggunakan cara mengidentifikasi sistem penting dan mekestraksi pada data yang didapatkan di suatu basis data. Secara sederhana data mining merupakan suatu penciptaan informasi terbaru dengan maksud mencari pola terpilih dari jumlah data yang sangat besar. Serangkaian cara untuk mendapatkan dan mencari nilai tambah pada data mining berupa pengetahuan yang di kelompokan data yang tidak diketahui secara manual .

\subsection{Tahapan Data Mining}

Pada tahapan ini data mining dilakukan dengan dari pemilihan data dari data ke sumber data target, Pada tahap pemahaman dan evaluasi data mining membentuk pengeluaran baru yang terbentuk pengertian baru[14], yang dapat memberikan jasa ke yang lebih baik. Ada beberapa tahapan berikut ini yaitu :

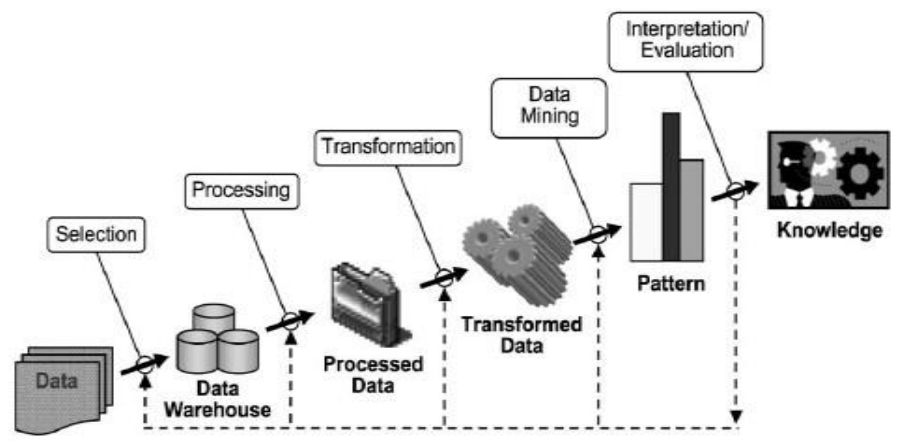

Gambar 2. Alur Pada Data Mining

1. Data Selection

Penyeleksian data yang telah di kumpulkan ke data operasional yang dilaksanakan sebelum tahap pencarian sebuah informasi di KDD dilakukan. Hasil penyeleksian data akan digunakan pada metode data mining yang akan menyimpan ke dalam berkas yang dipisah dari operasional basis data.

2. Pre-Processing / Cleaning

Pada saat pemprosesan data mining akan melakukan proses pembersihan di data yang berfokus ke KDD. Pembersihan data melingkup ke pembuangan data yang sama, data yang diperiksa berubah - ubah akan di perbaiki pada kesalahan data.

3. Transformation

Data yang telah di transformasi akan dipilih, maka data ini akan di lakukan pemrosesan di data mining, pemrosesan koding di KDD menggunakan cara yang unik dan bergantung di pola atau jenis laporan yang ditelusuri pada basis data

4. Data Mining

Menggunakan metode teknik nertentu dan mencari proses pola atau informasi menarik kedalam data yaitu data mining . Dalam data mining banyak teknik dan algoritma yang beragam. Penyeleksian dalam sistem atau algoritma yang baik akan sampai ke tujuan dan proses KDD secara keseluruhan

5. Interpretatiion / Evolution

Dalam data mining informasi yang akan di proses dapat di gambarkan ke bentuk yang mudah diterima, di pihak yang membutuhkan. Proses KDD merupakan bagian interpretation. Bagian yang dapat mengontrol suatu informasi dan pola yang telah ditemukan berbeda pada fakta atau asumsi yang mengarah ke sebelumnya[15].

\section{HASIL DAN PEMBAHASAN}

\subsection{Rancangan Use Case Diagram}


ISSN 2614-5278 (media cetak), ISSN 2548-8368 (media online)

Available Online at https://ejurnal.stmik-budidarma.ac.id/index.php/mib DOI 10.30865/mib.v5i3.3085

Use Case Diagram digambarkan dengan koneksi kepada para pengguna antara sistem aplikasi yang dibuat untuk menggambarkan interaksi satu atau lebih kepada pengguna aplikasi[17].

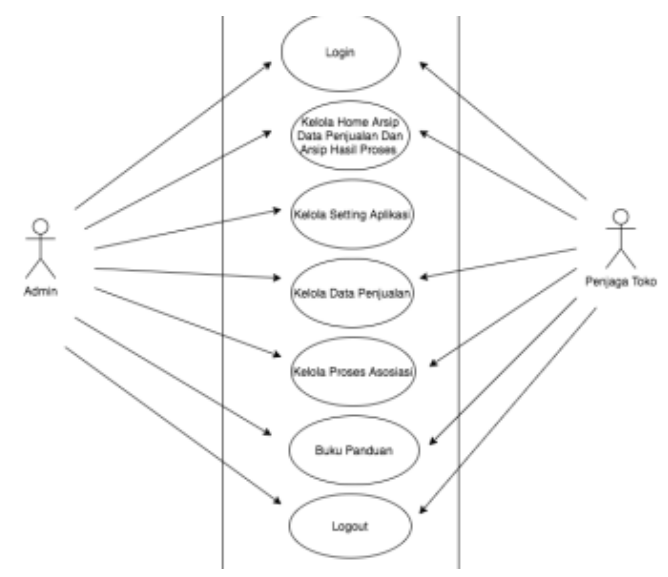

Gambar 3. Use Case Diagaram Toko Andra Jaya

\subsection{Implementasi Program}

Dalam penelitian diatas diperlukan nya perangkat lunak untuk mengimplementasikan algoritma apriori untuk mendapatkan sebuah rancangan data mining pada aplikasi web yang telah dibuat.

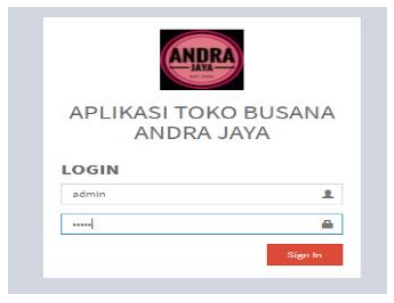

Gambar 4. Tampilan Login Toko Andra Jaya

Untuk membuka tampilan ke website andra jaya admin atau user harus menuju ke google lalu ketik https://localhost/andra jaya/index.php. Menu login tersebut akan menju ketempilan selanjutnya ke tampilan home.

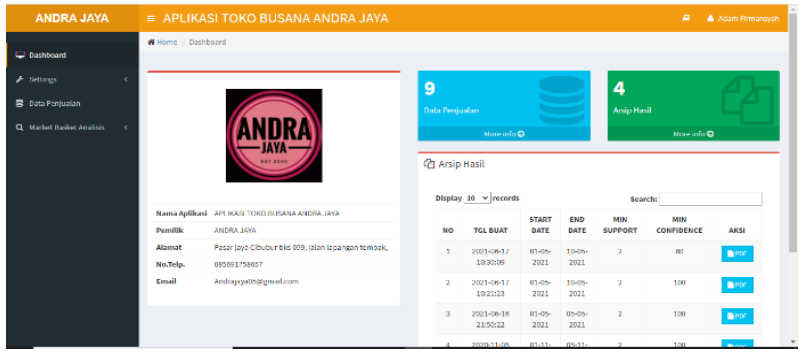

Gambar 5. Tampilan Home/Dasboard Andra Jaya

Pada tampilan home/dashboard terdapat pilihan berupa settings, data penjualan dan analisis market.

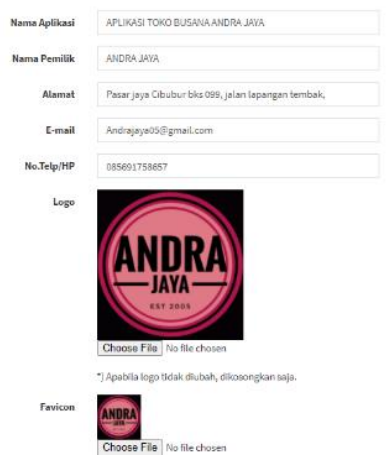

Gambar 6. Tampilan Settings Aplikasi 
ISSN 2614-5278 (media cetak), ISSN 2548-8368 (media online)

Available Online at https://ejurnal.stmik-budidarma.ac.id/index.php/mib DOI 10.30865/mib.v5i3.3085

Pada gambar 6 di atas adalah pilihan setting yaitu profil aplikasi yang dapat menginputkan sesuai yang tertera pada gambar.

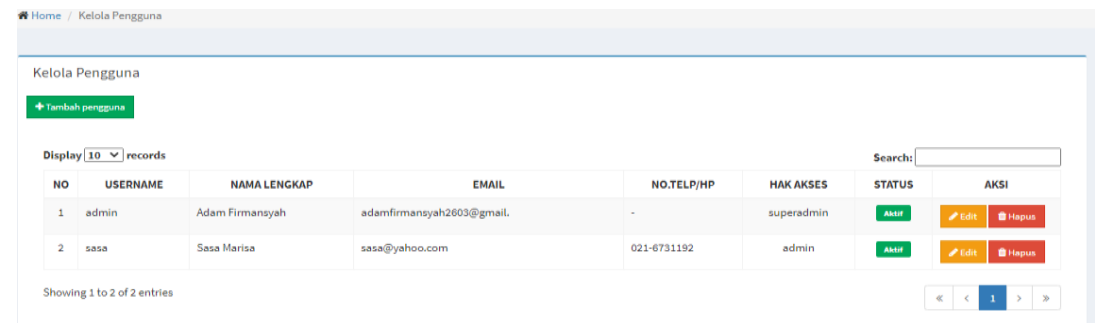

Gambar 7. Tampilan Settings Pengguna Aplikasi

Pada gambar 7 di atas adalah pilihan settings yaitu pengguna yang dapat mengubah atau menambahkan pengguna lain untuk melakukan login kedalam website toko andra jaya.

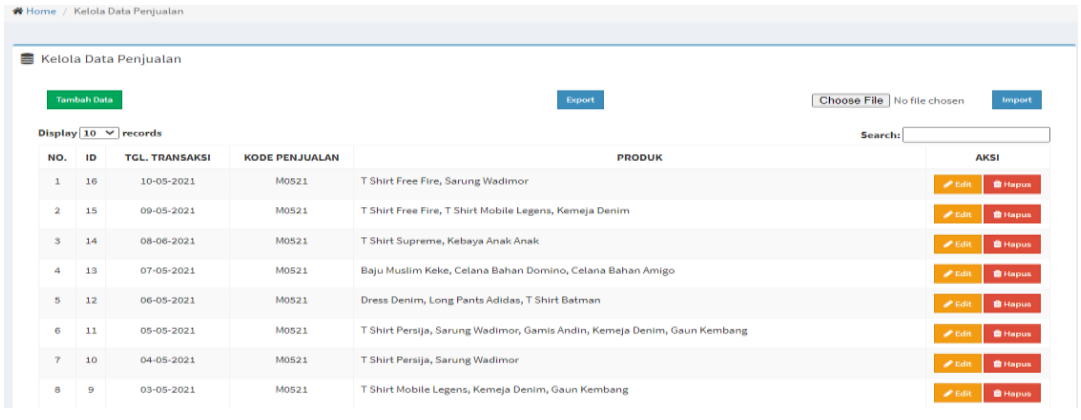

Gambar 8. Tampilan Menu Data Penjualan

Pada gambar 8 menunjukkan tampilan menu data penjualan dari toko andra jaya yang berfungsi untuk menambahkan barang atau item penjualan, mengexport data dan import data jika sudah mempunyai data sebelumnya.

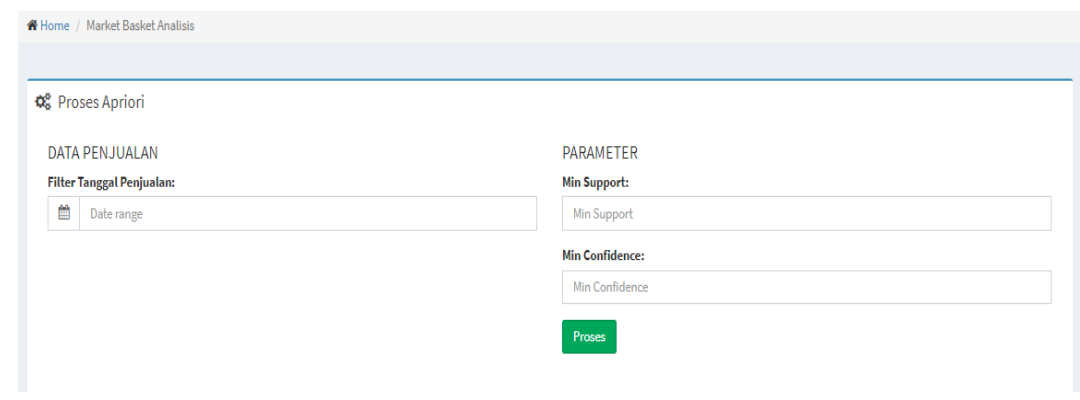

Gambar 9. Tampilan Proses Apriori

Pada gambar 9 menunjukkan tampilan dari proses apriori terdapat tanggal, minimal support dan minimal confidience, setelah di proses hasil akan keluar langsung di bawah pemerosesan dan juga dalam bentuk pdf dengan mencari tanggal yang di input.

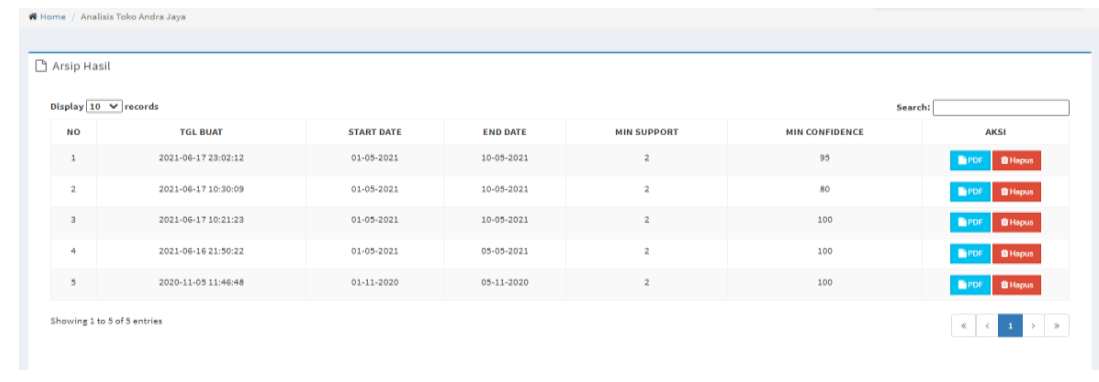

Gambar 10. Daftar Tampilan Hasil Proses Apriori

Pada gambar 10 menunjukkan hasil dari proses apriori, hasil dari proses apriori bisa di lihat dengan memilih tulisan pdf dan hasil yang telah di input. 
ISSN 2614-5278 (media cetak), ISSN 2548-8368 (media online)

Available Online at https://ejurnal.stmik-budidarma.ac.id/index.php/mib DOI 10.30865/mib.v5i3.3085

\section{PROSES HITUNG DAN HASIL MARKET BASKET ANALISIS (APRIORI)}

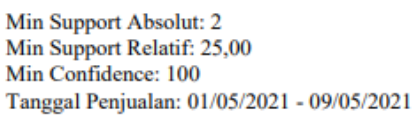

\section{PROSES HITUNG}

ITEMSET 1
\begin{tabular}{|c|l|c|c|c|}
\hline No & \multicolumn{1}{c|}{ Item } & Jumlah & Suppport & Keterangan \\
\hline 1 & T Shirt Free Fire & 2 & 25,00 & Lolos \\
\hline 2 & T Shirt Mobile Legens & 2 & 25,00 & Lolos \\
\hline 3 & Kemeja Denim & 4 & 50,00 & Lolos \\
\hline 4 & Celana Bahan Amigo & 1 & 12,50 & Tidak Lolos \\
\hline 5 & Celana Bahan Domino & 1 & 12,50 & Tidak Lolos \\
\hline 6 & Baju Muslim Keke & 1 & 12,50 & Tidak Lolos \\
\hline 7 & T Shirt Batman & 1 & 12,50 & Tidak Lolos \\
\hline 8 & Long Pants Adidas & 1 & 12,50 & Tidak Lolos \\
\hline 9 & Dress Denim & 1 & 12,50 & Tidak Lolos \\
\hline 10 & T Shirt Persija & 4 & 50,00 & Lolos \\
\hline 11 & Sarung Wadimor & 4 & 50,00 & Lolos \\
\hline 12 & Gaun Kembang & 3 & 37,50 & Lolos \\
\hline 13 & Gamis Andin & 1 & 12,50 & Tidak Lolos \\
\hline
\end{tabular}

Gambar 11. Proses Hitung Dari Item Set 1

Di gambar 11 menujukkan tabel yang berisi data penjualan dari toko andra jaya yang berisi 13 item, jumlah pembelian barang dan tanggal pembelian. Pada perhitungan item set ini minimum support $25 \%$ dan minimum confidience 100\%, penginputpan dari data tersebut pada tanggal 01-09 Mei 2021 dengan 13 item, dihasilkan penjualan yang sama dibeli pada 8 hari, pada nilai support dan dijelaskan item mana yang diterima dan tidak diterima .

ITEMSET 1 YANG LOLOS
\begin{tabular}{|c|l|c|c|}
\hline No & \multicolumn{1}{|c|}{ Item } & Jumlah & Suppport \\
\hline 1 & T Shirt Free Fire & 2 & 25,00 \\
\hline 2 & T Shirt Mobile Legens & 2 & 25,00 \\
\hline 3 & Kemeja Denim & 4 & 50,00 \\
\hline 4 & T Shirt Persija & 4 & 50,00 \\
\hline 5 & Sarung Wadimor & 4 & 50,00 \\
\hline 6 & Gaun Kembang & 3 & 37,50 \\
\hline
\end{tabular}

Gambar 12. Item Set 1 Yang lolos

Pada gambar 12 menunjukkan item set satu yang lolos dari nilai support $25 \%$.

ITEMSET 2 YANG LOLOS

\begin{tabular}{|c|l|l|c|c|}
\hline No & \multicolumn{1}{|c|}{ Item 1 } & \multicolumn{1}{c|}{ Item 2 } & Jumlah & Suppport \\
\hline 1 & T Shirt Mobile Legens & Kemeja Denim & 2 & 25,00 \\
\hline 2 & Kemeja Denim & T Shirt Persija & 2 & 25,00 \\
\hline 3 & Kemeja Denim & Sarung Wadimor & 2 & 25,00 \\
\hline 4 & Kemeja Denim & Gaun Kembang & 3 & 37,50 \\
\hline 5 & T Shirt Persija & Sarung Wadimor & 4 & 50,00 \\
\hline 6 & T Shirt Persija & Gaun Kembang & 2 & 25,00 \\
\hline 7 & Sarung Wadimor & Gaun Kembang & 2 & 25,00 \\
\hline
\end{tabular}

Gambar 13. Item Set 2 Yang Lolos

Pada gambar 13 menunjukkan item set 2 yang lolos dan telah dikombinasikan menjadi dua item. Didapatkan dari hasil nilai minimum support, lalu memilih barang yang telah ditentukan di mode frekuensi tinggi, rumus perhitungan tersebut yaitu $2 / 8 \times 100 \%=25$ contoh kasus T Shirt Mobile Legends dan Kemeja Denim.

ITEMSET 3 YANG LOLOS
\begin{tabular}{|c|l|l|l|c|c|}
\hline No & \multicolumn{1}{|c|}{ Item 1 } & \multicolumn{1}{|c|}{ Item 2 } & \multicolumn{1}{|c|}{ Item 3 } & Jumlah & Suppport \\
\hline 1 & T Shirt Persija & Kemeja Denim & Sarung Wadimor & 2 & 25,00 \\
\hline 2 & T Shirt Persija & Kemeja Denim & Gaun Kembang & 2 & 25,00 \\
\hline 3 & Sarung Wadimor & Kemeja Denim & Gaun Kembang & 2 & 25,00 \\
\hline 4 & Sarung Wadimor & T Shirt Persija & Gaun Kembang & 2 & 25,00 \\
\hline
\end{tabular}

Gambar 14. Item Set 3 Yang Lolos

Pada gambar 14 menunjukkan bahwa item set 3 ini berisi kombinasi dari item set 2 yang didapat dari data item set 2 . 
ISSN 2614-5278 (media cetak), ISSN 2548-8368 (media online)

Available Online at https://ejurnal.stmik-budidarma.ac.id/index.php/mib DOI 10.30865/mib.v5i3.3085

\begin{tabular}{|c|c|c|c|c|c|}
\hline No & $\mathbf{X} \Rightarrow \mathbf{Y}$ & Support X U Y & Support X & Confidence & Keterangan \\
\hline 1 & $\begin{array}{l}\text { T Shirt Persija, Kemeja Denim } \\
=>\text { Sarung Wadimor }\end{array}$ & 25,00 & 25,00 & 100,00 & Lolos \\
\hline 2 & $\begin{array}{l}\text { Kemeja Denim, Sarung } \\
\text { Wadimor }=>\text { T Shirt Persija }\end{array}$ & 25,00 & 25,00 & 100,00 & Lolos \\
\hline 3 & $\begin{array}{l}\text { Sarung Wadimor, T Shirt } \\
\text { Persija }=>\text { Kemeja Denim }\end{array}$ & 25,00 & 50,00 & 50,00 & Tidak Lolos \\
\hline 4 & $\begin{array}{l}\text { T Shirt Persija }=>\text { Sarung } \\
\text { Wadimor, Kemeja Denim }\end{array}$ & 25,00 & 50,00 & 50,00 & Tidak Lolos \\
\hline 5 & $\begin{array}{l}\text { Kemeja Denim }=>\text { T Shirt } \\
\text { Persija, Sarung Wadimor }\end{array}$ & 25,00 & 50,00 & 50,00 & Tidak Lolos \\
\hline 6 & $\begin{array}{l}\text { Sarung Wadimor }=>\text { Kemeja } \\
\text { Denim, T Shirt Persija }\end{array}$ & 25,00 & 50,00 & 50,00 & Tidak Lolos \\
\hline 7 & $\begin{array}{l}\text { T Shirt Persija , Kemeja Denim } \\
=>\text { Gaun Kembang }\end{array}$ & 25,00 & 25,00 & 100,00 & Lolos \\
\hline 8 & $\begin{array}{l}\text { Kemeja Denim, Gaun } \\
\text { Kembang }=>\text { T Shirt Persija }\end{array}$ & 25,00 & 37,50 & 66,67 & Tidak Lolos \\
\hline 9 & $\begin{array}{l}\text { Gaun Kembang, T Shirt Persija } \\
=>\text { Kemeja Denim }\end{array}$ & 25,00 & 25,00 & 100,00 & Lolos \\
\hline 10 & $\begin{array}{l}\text { T Shirt Persija }=>\text { Gaun } \\
\text { Kembang, Kemeja Denim }\end{array}$ & 25,00 & 50,00 & 50,00 & Tídak Lolos \\
\hline 11 & $\begin{array}{l}\text { Kemeja Denim = > T Shirt } \\
\text { Persija, Gaun Kembang }\end{array}$ & 25,00 & 50,00 & 50,00 & Tídak Lolos \\
\hline 12 & $\begin{array}{l}\text { Gaun Kembang = > Kemeja } \\
\text { Denim, T Shirt Persija }\end{array}$ & 25,00 & 37,50 & 66,67 & Tidak Lolos \\
\hline 13 & $\begin{array}{l}\text { Sarung Wadimor, Kemeja } \\
\text { Denim }=>\text { Gaun Kembang }\end{array}$ & 25,00 & 25,00 & 100,00 & Lolos \\
\hline 14 & $\begin{array}{l}\text { Kemeja Denim, Gaun } \\
\text { Kembang = > Sarung Wadimor }\end{array}$ & 25,00 & 37,50 & 66,67 & Tidak Lolos \\
\hline
\end{tabular}

Gambar 15. Confidience Item Set 3

Pada gambar 15 Menunjukkan keterangan confidience item set 3 diterima dan tidak diterima, pada tabel confidience item set 3 diperoleh lah hasil dari nilai confidience menghitung menggunakan nilai support X U Y nilai support $\mathrm{X}$ bisa diambil di nilai support item set 2 dan item set 1 .

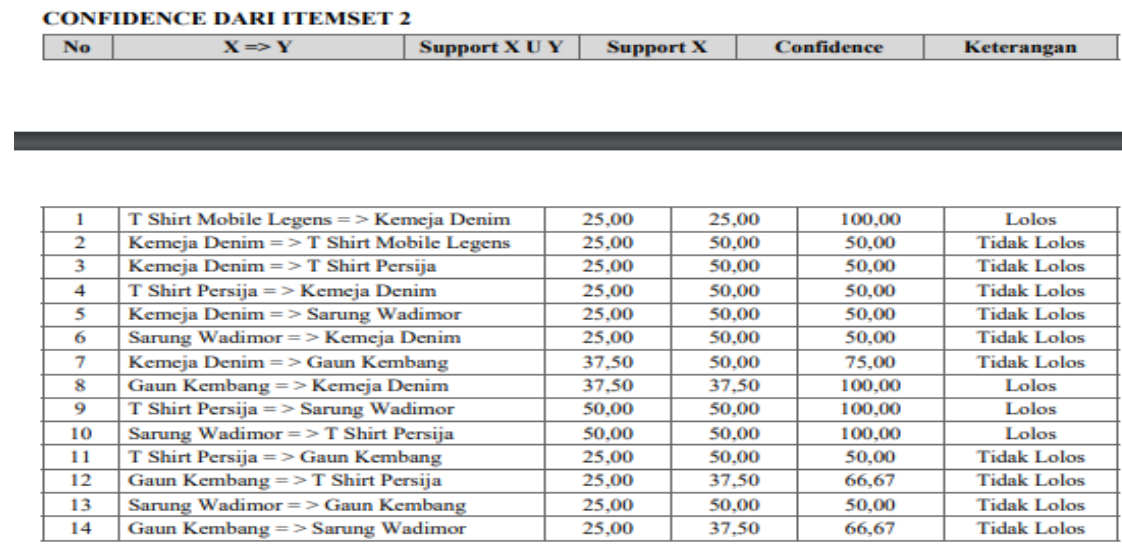

Gambar 16. Confidience Item Set 2

Pada gambar 16 menunjukkan keterangan confidience item set 2 diteriman dan tidak diterima, pada tabel confidience item set 2 diperoleh lah hasil nilai confidience menggunakan cara menjumlahkan nilai support X U Y nilai support $\mathrm{X}$ bisa diambil di nilai support item set 2 dan item set 1 .

HASIL

\begin{tabular}{|c|c|c|c|c|}
\hline No & $\mathbf{X}=>\mathbf{Y}$ & Confidence & Nilai Uji lift & Korelasi rule \\
\hline 1 & $\begin{array}{l}\text { T Shirt Persija, Kemeja Denim = > Sarung } \\
\text { Wadimor }\end{array}$ & 100,00 & 2,00 & korelasi positif \\
\hline 2 & $\begin{array}{l}\text { Kemeja Denim, Sarung Wadimor }=>\text { T } \\
\text { Shirt Persija }\end{array}$ & 100,00 & 2,00 & korelasi positif \\
\hline 3 & $\begin{array}{l}\text { T Shirt Persija , Kemeja Denim = > Gaun } \\
\text { Kembang }\end{array}$ & 100,00 & 2,67 & korelasi positif \\
\hline 4 & $\begin{array}{l}\text { Gaun Kembang , T Shirt Persija = > Kemeja } \\
\text { Denim }\end{array}$ & 100,00 & 2,00 & korelasi positif \\
\hline 5 & $\begin{array}{l}\text { Sarung Wadimor , Kemeja Denim => Gaun } \\
\text { Kembang }\end{array}$ & 100,00 & 2,67 & korelasi positif \\
\hline 6 & $\begin{array}{l}\text { Gaun Kembang, Sarung Wadimor => } \\
\text { Kemeja Denim }\end{array}$ & 100,00 & 2,00 & korelasi positif \\
\hline 7 & $\begin{array}{l}\text { T Shirt Persija , Gaun Kembang = > Sarung } \\
\text { Wadimor }\end{array}$ & 100,00 & 2,00 & korelasi positif \\
\hline 8 & $\begin{array}{l}\text { Gaun Kembang, Sarung Wadimor }=>T \\
\text { Shirt Persija }\end{array}$ & 100,00 & 2,00 & korelasi positif \\
\hline 9 & T Shirt Mobile Legens $=>$ Kemeja Denim & 100,00 & 2,00 & korelasi positif \\
\hline 10 & Gaun Kembang $=>$ Kemeja Denim & 100,00 & 2,00 & korelasi positif \\
\hline 11 & T Shirt Persija $=>$ Sarung Wadimor & 100,00 & 2,00 & korelasi positif \\
\hline 12 & Sarung Wadimor $=>$ T Shirt Persija & 100,00 & 2,00 & korelasi positif \\
\hline
\end{tabular}

Gambar 17. Hasil Asosiasi Terbentuk

Pada gambar 17 hasil yang didapatkan dari item set 1,2 dan 3 dengan nilai confidience $100 \%$. 


\section{KESIMPULAN}

Telah didapat hasil pembahsan ini dengan memakai algoritma apriori dengan judul "Penerapan Rancang Bangun Metode Data Mining Pada Point of Sale Berbasis Web Menggunakan Algoritma Apriori” dengan melakukan penelitian disebuah toko Andra Jaya mempunyai kesimpulan seperti ini. Dengan aplikasi yang dibuat ini penjaga toko jadi lebih singkat mengetahui barang dagangan yang terjual lebih banyak dan tidak terjual lebih banyak Dengan confidience yang tinggi, pada penjualan selanjutnya dapat mengetahui pola pembelian dari konsumen.Algoritman apriori dapat di implementasikan untuk menemukan pola asosiasi penjualan barang data transaksi penjualan. Nilai minimum support menjadi parameter terhadapap jumlah kandidat yang diperoleh. Nilai confidience menjadi parameter yang mempengaruhi jumlah asosisasi terbentuk.

\section{REFERENCES}

[1] C.Pradeepkumar and S.Loganathan, "Penerapan Metode Asosiasi Menggunakan Algoritma Apriori Pada Aplikasi Pola Belanja Konsumen ( Studi Kasus Toko Buku Gramedia Bintaro )," Int. J. Sci. Eng. Res. (IJOSER), vol. 3, no. 4, pp. 120127, 2015, [Online]. Available: http://journal.uinjkt.ac.id/index.php/ti/article/view/5602/3619.

[2] Amrin Amrin, "Data Mining Dengan Algoritma Apriori untuk Penentuan Aturan Asosiasi Pola Pembelian Pupuk," Paradigma, vol. XIX, no. 1, pp. 74-79, 2017, doi: https://doi.org/10.31294/p.v19i1.1836.

[3] A. Setiawan and F. P. Putri, "Implementasi Algoritma Apriori untuk Rekomendasi Kombinasi Produk Penjualan," vol. XII, no. 1, pp. 66-71, 2020.

[4] I. Djamaludin et al., "Analisis pola pembelian konsumen pada transaksi penjualan menggunakan algoritma apriori," vol. 8, no. 2, pp. 671-678, 2017.

[5] D. Fernando, "PENERAPAN DATA MINING REKOMENDASI BUKU MENGGUNAKAN ALGORITMA APRIORI," vol. 7, no. 1, pp. 50-56, 2020.

[6] B. A. Najib and N. Suryani, "Penerapan Data Mining Terhadap Data Penjualan Lapis Bogor Sangkuriang Dengan Metode Algoritma Apriori," vol. VI, no. 1, pp. 61-70, 2020, doi: 10.31294/jtk.v4i2.

[7] S. Budiman and S. P. A. Kesehatan, "Data Mining Apriori."'

[8] M. B. Program et al., "Algoritma Asosiasi Dengan Algoritma Apriori Untuk Analisa Data Penjualan," J. Pilar Nusa Mandiri, vol. XII, no. 2, pp. 121-129, 2016, [Online]. Available: http://ejournal.nusamandiri.ac.id/index.php/pilar/article/view/266.

[9] D. Sepri and M. Afdal, "Analisa Dan Perbandingan Metode Algoritma Apriori Dan Fp-Growth Untuk Mencari Pola Daerah Strategis,” J. Sist. Inf. Kaputama, vol. 1, no. 1, pp. 47-55, 2017.

[10] D. D. Prayitno, "Ekstraksi Pola Hubungan Penerimaan Mahasiswa Baru Dengan Sebaran Wilayah Asal Sekolah Menggunakan ARM Algoritma Apriori," J. Tek. Inform. dan Sist. Inf., vol. 3, no. 1, pp. 46-56, 2017, doi: 10.28932/jutisi.v3i1.566.

[11] A. F. Lestari and M. Hafiz, "Penerapan Algoritma Apriori Pada Data Penjualan Barbar Warehouse," INOVTEK Polbeng - Seri Inform., vol. 5, no. 1, p. 96, 2020, doi: 10.35314/isi.v5i1.1317.

[12] P. Itb, A. Dahlan, D. E. Sastie, and A. B. Pohan, "Analisa Algoritma Apriori Pada Pola Peminjaman Buku di,” vol. 4, pp. 136-143, 2020, doi: 10.30865/mib.v4i1.1475.

[13] Z. NURZANI and K. D. TANIA, "Analysis of Transactions 212 Mart Kuto Palembang to Find Frequent Patterns Among Itemset Using Association Rule Mining," vol. 172, no. Siconian 2019, pp. 325-332, 2020, doi: 10.2991/aisr.k.200424.049.

[14] R. Takdirillah, "Penerapan Data Mining Menggunakan Algoritma Apriori Terhadap Data Transaksi Sebagai Pendukung Informasi Strategi Penjualan," Edumatic J. Pendidik. Inform., vol. 4, no. 1, pp. 37-46, 2020, doi: 10.29408/edumatic.v4i1.2081.

[15] T. Akhir, "Sistem Rekomendasi Promo Pada Minimarket Menggunakan Algoritma Apriori," 2020.

[16] "PENERAPAN METODE ASSOCIATION RULE MINING UNTUK ANALISIS DAN IMPLEMENTASI TEKNIK DATA MINING DALAM MEMPREDIKSI," pp. 151-160.

[17] H. N. Wulandari and N. W. Rahayu, "Pemanfaatan Algoritma Apriori untuk Perancangan Ulang Tata Letak Barang di Toko Busana," Semin. Nas. Apl. Teknol. Inf. ( SNATI ), vol. 6, no., p. D-33-D-38, 2014. 